\title{
PERBEDAAN STRATEGI PEMBELAJARAN SOSIODRAMA DAN PRESENTASI DALAM PROSES PEMBELAJARAN
}

\author{
Nandhini Hudha Anggarasari \\ PG PAUD FKIP Universitas Muhammadiyah Tasikmalaya \\ nandhini.hagrs@umtas.ac.id
}

\begin{abstract}
Abstraksi
Penelitian ini bertujuan untuk mengetahui perbedaan strategi pembelajaran sosiodrama dan presentasi. Dugaan awal yang diajukan dalam penelitian ini adalah ada perbedaan antara strategi pembelajaran sosiodrama dan presentasi. Strategi pembelajaran sosiodrama lebih efektif dalam penyerapan informasi pada mahasiswa daripada pembelajaran presentasi.

Subjek penelitian adalah semua mahasiswa yang ada di kelas psikologi perkembangan di A dan B. Peneliti memberikan posttest setiap selesai melakukan presentasi dan sosiodrama di masing-masing kelas, kemudian mereview proses pembelajaran. Posttest dilakukan dalam 12 kali pertemuan.

Metode penelitian yang digunakan adalah eksperimen Posttest Only, Equivalent Control Group Design, yaitu subjek yang diberi perlakuan merupakan keseluruhan subjek dalam kelompok tersebut. Metode analisis data dilakukan dalam penelitian ini menggunakan fasilitas program SPSS versi IBM 22,00 dan analisis data deskriptif dari hasil observasi. Teknik analisis uji U-Mann Whitney test menunjukkan skor $p>0,05$ yang artinya tidak ada perbedaan antara menggunakan strategi pembelajaran sosiodrama dan presentasi. Namun, dari hasil rata-rata nilai posttest kelas, ditemukan bahwa kelas yang menggunakan metode sosiodrama memiliki nilai rata-rata yang lebih tinggi daripada metode presentasi.

Kata kunci : strategi pembelajaran; sosiodrama; presentasi
\end{abstract}

\section{Abstract}

This study aims to determine the differences in learning strategies sociodrama and presentation. Initial allegations put forward in this study is there is a difference between learning strategies sociodrama and presentation. Sociodramas more effective learning strategies in the uptake of information on student learning rather than presentation. Subjects numbered are all students in the class in the A and B. Researchers gave posttest after each presentation and sociodramas in each class, and then reviewing the learning process. Posttest conducted in 12 meetings.

The method used was experimental posttest Only, Equivalent Control Group Design, the subject being treated is a whole subject in the group. Methods of data analysis performed in this study using the facilities of IBM SPSS version 22.00 and descriptive data analysis of the results of observation. Engineering test analysis Mann Whitney U-test showed score $\mathrm{p}>0.01$, which means there is no difference between the use of learning strategies sociodrama and presentation. However, the results of the average posttest value, it was found that the class using sociodramas method has an average value higher than the method of presentation.

Keywords: learning strategies; sociodramas; presentation 


\section{Pendahuluan}

Masa depan bangsa ada di tangan generasi muda, generasi muda dididik dan berkembang dalam lingkungan keluarga dan masyarakat. Perkembanagan individu dari masa kanak-kanak, remaja, dewasa, hingga lansia. Remaja merupakan masa peralihan dari anak-anak menjadi dewasa. Tahap peralihan dari masa remaja hingga dewasa, dimulai dari tahap dewasa muda. Dewasa muda merupakan masa transisi, baik transisi secara fisik, intelektual, maupun transisi peran sosial. Masa transisi fisik pada dewasa muda tidak lagi sama seperti saat masa remaja. Pada masa ini, individu dapat dikatakan matang untuk melakukan tugas-tugas dewasa muda yang lainnya, seperti bekerja, menikah, dan mempunyai anak. Masa ini ditandai dengan perubahan secara fisik, seperti tumbuhnya bulu-bulu halus, perubahan suara, menstruasi pada wanita, dan kemampuan reproduksi. (Dariyo, 2003)

Masa transisi peran sosial dewasa muda berubah. Pada masa ini, mereka akan melanjutkan hubungan dengan pacarnya, menikah dan mengurus keluarga baru. Tinggal berjauhan dengan orangtuanya dan saling membina kebutuhan rumah tangga mereka. Mereka juga berbaur dengan masyarakat sekitar dan membina hubungan silaturrahmi. (Dariyo, 2003)

Masa transisi intelektual pada dewasa muda, menurut Piaget (Dariyo, 2003), kapasitas intelektual dewasa muda tergolong masa operasional formal, bahkan kadangkadang mencapai masa post operasi formal. Taraf ini menyebabkan, dewasa muda mampu memecahkan masalah yang kompleks dengan kapasitas berpikir abstrak, logis, dan rasional. Sebagian besar dewasa muda lulus dari SMU dan masuk perguruan tinggi, kemudian mengembangkan kariernya dengan bekerja. Namun, pada masa ini bila individu tidak dapat memecahkan masalahnya dan cenderung minta bantuan terus dengan orang lain, maka akan menimbulkan rasa malu, karena tidak sama dengan orang lain yang lebih survive terhadap masalah-masalah hidup yang dialami.

Peran guru untuk mengembangkan dan meningkatkan kapasitas berpikir abstrak, logis, dan rasional dapat diawali dengan penerapan strategi dalam proses pembelajaran yang tepat. Menurut Kemp (Majid, 2016) strategi pembelajaran adalah suatu kegiatan pembelajaran yang harus dikerjakan oleh guru dan peserta didik agar tujuan pembelajaran dapat tercapai. Sedangkan menurut Gerlach dan Ely (Majid, 2016) strategi pembelajaran adalah cara-cara yang dipilih untuk menyampaikan materi pembelajaran 
dalam lingkup pembelajaran tertentu. Metode pembelajaran berkembang dari zaman ke zaman, pengembangan metode pembelajaran meliputi metode ceramah, demonstrasi, diskusi, simulasi, tugas dan resitasi, tanya jawab, kerja kelompok, problem solving, sistem regu, latihan, karya wisata, ekspositori, inkuiri, hingga pembelajaran secara kontekstual (Majid, 2016).

Pengembangan metode pembelajaran ada pula yang menggunakan sosiodrama. Menurut Winkel (Zuhara, 2015) sosiodrama merupakan salah satu strategi pembelajaran yang mendorong individu untuk saling berinteraksi satu sama lain dan memecahkan permasalahan. Sosiodrama merupakan metode mengajar dengan cara mempertunjukkan kepada peserta didik tentang masalah-masalah hubungan sosial, untuk mencapai tujuan pengajaran tertentu. Masalah hubungan sosial tersebut didramatisasikan oleh peserta didik dibawah pimpinan guru. Melalui metode ini guru ingin mengajarkan cara-cara bertingkah laku dalam hubungan antara sesama.

Menurut Harsini (2015), metode sosiodrama dapat meningkatkan keaktifan dan hasil belajar siswa SD pada pelajaran PkN. Metode ini juga meningkatkan keterampilan komunikasi peserta didik untuk menyampaikan ide, pertanyaan, dan harapannya peserta didik (Erawan, 2014). Senada pula dengan penelitian Zuhara (2015), yang mengungkapkan bahwa metode sosiodrama dapat meningkatkan komunikasi interpersonal pada siswa SMA.

Adapun jenis metode sosio drama menurut Harsini (2015) adalah: 1) Permainan Penuh. Permainan penuh dapat digunakan untuk proyek besar yang tidak dibatasi waktu dan sumber. Permainan penuh ini merupakan alat yang sangat baik untuk menangani masalah yang kompleks dan kelompok yang berhubungan dengan masalah itu. Permainan mungkin asli atau disesuaikan dengan situasi, untuk memenuhi permintaan distributor komersial atau organisasi perjuangan, keagamaan, sosial, pendidikan, industri, dan professional; 2) Pementasan situasi atau kreasi baru; Teknik ini mungkin setingkat dengan permainan penuh, tetapi dirancang hanya untuk memainkan sebagian masalah atau situasi. Bentuk permainan drama memerlukan orientasi awal dan diskusi tambahan atau pengembangan lanjutan kesimpulan dengan menggunakan metode lain. Pementasan situasi dapat digunakan untuk memerankan kembali persidangan pengadilan, pertemuan dan persidangan badan legislatif; 3) Playlet. Playlet meliputi kegiatan berskala kecil untuk menangani masalah kecil atau bagian kecil dari masalah 
besar. Jenis ini dapat digunakan secara tunggal atau untuk mengemas pementasan masalah yang menggunakan metode lain, atau serangkaian playlet dapat digunakan bersama untuk menggambarkan perkembangan masalah secara bertahap; 4) Blackout. Blackout adalah jenis permainan drama yang ke empat. Jenis ini biasanya hanya meliputi dua atau tiga orang dengan dialog singkat mengembangkan latar belakang secukupnya dalam pementasan yang cepat berakhir.

Menurut Harsini (2015), "langkah-langkah yang biasa berhubungan dengan proses permainan peran adalah:

1. Menentukan Masalah. Partisipan kelompok dalam memilih dan menentukan masalah sangat diperlukan. Masalah harus signifikan dan cukup dikenal oleh pemain maupun pengamat. Masalah harus valid, jelas, dan sederhana sehingga peserta dapat mendiskusikan secara rasional. Diperlukan kehati-hatian untuk menghindari masalah yang dapat mengungkapkan isu yang tersembunyi, tetapi menyimpang dari tujuan permainan peran. Dalam hal ini, baik pengamat maupun pemain harus benar-benar mengerti permasalahannya. Sebagai contoh, petani penyewa mencoba meyakinkan tuan tanah untuk membantu mereka membeli benih unggul untuk meningkatkan produksi.

2. Membentuk Situasi. Desain peran yang dimainkan atau situasi tergantung pada hasil yang diinginkan. Kehati-hatian perlu diambil untuk menghindari situasi yang kompleks, yang mungkin mengacaukan perhatian pengamat dari masalah yang dibahas. Situasi harus memberikan sesuatu yang nyata kepada pemain dan kelompok, dan dapat saat yang sama memberikan pandangan umum dan pengetahuan yang diinginkan.

3. Membentuk Karakter. Keberhasilan proses permainan peran sering ditentukan oleh peran dan pemain yang layak dipilih. Peran yang akan dimainkan harus dipilih secara hati-hati. Pilihlah peran yang akan memberikan sumbangan untuk mencapai tujuan pertemuan. Biasanya, permainan peran melibatkan peran yang sedikit. Pemain yang terbaik harus dipilih untuk setiap peran. Peran-peran harus diberikan kepada mereka yang mampu membawakannya dengan baik dan mau melakukannya. Orang tidak seharusnya dipaksa memainkan suatu peran, tidak pula harus diminta untuk memainkan peran yang mungkin membuat bingung setelah penyajian. 
4. Mengarahkan Pemain Permainan yang spontan tidak memerlukan pengarahan. Akan tetapi, permainan peran yang terencana memerlukan pengarahan dan perencanaan yang matang. Penting bagi pemain untuk dapat memainkan perannya pada saat yang tepat dan sesuai dengan tujuan yang diinginkannya. Pengarahan diperlukan untuk memberitahukan tanggungjawab mereka sebagai pemain. Pengarahan mungkin dilakukan secara resmi atau tidak resmi, tergantung situasi dan pengarahan tidak harus menentukan apa yang harus dikatakan atau dilakukan.

5. Memahami Peran, Biasanya, suatu hal yang baik bagi pengamat untuk tidak mengetahui peran apa yang sedang dimainkan. Permainan harus diatur waktunya secara hati-hati dan spontan. Penting untuk diketahui, apabila ada beberapa pemain, hendaknya mereka mulai bermain pada saat yang sama dan berakhir pada saat yang sama pula, yaitu ketika permainan dihentikan. Menghentikan/memotong. Efektifitas permainan peran mungkin sangat berkurang jika permainan dihentikan terlalu cepat atau dibiarkan berlangsung terlalu lama. Pengaturan waktu sangat penting. Permainan peran yang lama tidak efektif, jika sebenarnya hanya diperlukan beberapa menit untuk memainkan peran yang diinginkan. Permainan harus dihentikan sesegera mungkin setelah permainan dianggap cukup bagi kelompok untuk menganalisis situasi dan arah yang ingin dimabil. Dalam beberapa kasus, perminan dapat dihentikan apabila kelompok sudah dapat memperkirakan apa yang akan terjadi jika permainan tetap diteruskan, dan permainan harus dihentikan jika pemain mengalami kebuntuan yang disebabkan penugasan atau pengarahan yang kurang memadai.

6. Mendiskusikan dan menganalisis permainan. Langkah terakhir ini harus menjadi "pembersih". Jika peranan dimainkan dengan baik, pengertian pengamat terhadap masalah yang dibahas akan semakin baik. Diskusi harus lebih difokuskan pada fakta dan prinsip yang terkandung daripada evaluasi pemain. Suatu ide yang baik, jika membiarkan pemain mengekspresikan pandangan mereka terlebih dahulu. Ada saatnya bagi pengamat untuk menganalisis, yaitu setelah pemain mengekspresikan diri."

Selain metoda sosiodrama, ada pula pengembangan strategi pembelajaran lain, salah satunya yaitu dengan metode presentasi. Menurut Djamarah dan Zain (Purbowati, 2016) metode diskusi presentasi adalah cara penyajian pelajaran, dimana peserta didik 
dihadapkan kepada suatu masalah yang bisa berupa pernyataan ataupun pertanyaan yang bersifat problematik untuk dibahas dan dipecahkan. Pada metode pembelajaran ini siswa bekerjasama dalam sebuah kelompok, dalam waktu yang telah ditentukan sekelompok siswa tersebut harus menyelesaikan segala permasalahan pernyataan atau pertanyaan tersebut dalam sebuah tulisan yang nantinya akan dipresentasikan di depan temannya agar ide gagasan yang telah mereka diskusikan dapat diketahui dan dipahami kelompok yang lain. Sehingga proses pembelajaran menjadi hidup dan menyenangkan. Penelitian Purbowati (2016) mengungkapkan bahwa ada perbedaan antara metode jigsaw dengan presentasi, untuk siswa SMA, lebih efektif menggunakan metode presentasi.

Berdasarkan uraian diatas, bahwa metode sosiodrama dan presentasi memiliki kelebihan-kelebihan yang mendukung proses pembelajaran, oleh karena itu peneliti tertarik untuk membandingkan metode sosiodrama dan presentasi, untuk mengetahui metode pembelajaran yang lebih efektif untuk dewasa awal (mahasiswa).

\section{Metode Penelitian}

Peneliti menggunakan metode eksperimen Posttest Only, Equivalent Control Group Design, yaitu subjek yang diberi perlakuan merupakan keseluruhan subjek dalam kelas tersebut (Latipun, 2004). Peneliti melakukan perbandingan metode pembelajaran pada dua kelas. Kelas A menggunakan strategi pembelajaran sosiodrama dan kelas B menggunakan strategi pembelajaran presentasi. Pada penelitian ini Peneliti memberikan posttest setiap selesai melakukan presentasi dan sosiodrama di masing-masing kelas, kemudian mereview proses pembelajaran. Posttest dilakukan dalam 12 kali pertemuan.

Data yang diperoleh adalah data kuantitatif. Metode analisis data digunakan untuk menguji hipotesis penelitian ini, yaitu menggunakan teknik analisis uji U-Mann Whitney test. Untuk menjaga keakuratan dan kemudahan pengolahan data digunakan teknik perhitungan data melalui program Software Statistical Product and Service Solution (SPSS) IBM 22.00 for Windows.

\section{Hasil dan Pembahasan}

Berdasarkan Hasil analisis U-Mann Whitney test, gain score diperoleh skor $\mathrm{p}$ sebesar 1,000 (2-tailed). Sehingga skor $\mathrm{p}>0,05$. Hal ini menunjukkan tidak adanya 
perbedaan yang sangat signifikan antara strategi pembelajaran sosiodrama dengan strategi pembelajaran presentasi. Sehingga Strategi pembelajaran sosiodrama sama efektifnya dalam penyerapan informasi pada mahasiswa dengan pembelajaran presentasi. Namun, dari hasil rata-rata nilai, ditemukan bahwa kelas A memiliki ratarata nilai posttest 37,07 dan nilai rata-rata kelompok B 33,25. Melihat nilai rata-rata kelompok, dapat diketahui bahwa strategi pembelajaran sosiodrama leih efektif daripada metode presentasi.

Berdasarkan hasil observasi ditemukan bahwa ada beberapa hal yang mempengaruhi dalam proses pembelajaran. Pada pembelajaran menggunakan presentasi, ada beberapa mahasiswa yang kurang mampu dalam kerjasama, tidak memahami materi secara mendalam, tidak menggunakan informasi dari banyak referensi pendukung, pertanyaan-pertanyaan yang multi kasus, kadang sulit dicerna karena minimnya informasi. Pada pembelajaran yang menggunakan strategi sosiodrama, faktor yang cukup mempengaruhi adalah mahasiswa kurang mampu dalam kerjasama, ada beberapa yang mendominasi dan ada yang hanya sebagai pengikut saja, kurangnya dalam membaca referensi yang majemuk, kurangnya memahami materi yang akan disampaikan, kurang tepat dalam mengkonversikan materi ke dalam sosiodrama.

\section{Simpulan}

Pada penelitian ini, berdasarkan data analisa, ditemukan tidak ada perbedaan antara metode sosiodrama dan presentasi, namun berdasarkan hasil nilai rata-rata kelas, ditemukan bahwa kelas yang menggunakan metode sosiodrama lebih tinggi nilai rataratanya daripada kelas yang menggunakan metode presentasi.

Saran untuk peneliti selanjutnya bila akan menggunakan strategi sosiodrama dan presentasi adalah perlu mempertimbangkan aspek dan kondisi lain dari mahasiswa yang 
beragam, misalnya motivasi dalam berprestasi, dan minat dalam membaca literasi sebagai proses pencarian informasi terkait tema yang akan dibahas. 


\section{Daftar Pustaka}

Dariyo,A.2002. Psikologi Perkembangan Remaja. Jakarta : Ghalia Indonesia.

Erawan,D.G.B. 2014. Penggunaan Metode Sosiodrama Untuk Meningkatkan Kemampuan Berwawancara Dengan Berbagai Kalangan Pada Siswa Kelas Viii Smp Mutiara Singaraja. Jurnal Santiaji Pendidikan, Volume 4, Nomor 1, Januari 2014, ISSN 2087-9016.

Hardini,T. 2015. Peningkatan Keaktifan Dan Hasil Belajar Siswa Dalam Pembelajaran Pkn Melalui Metode Sosiodrama Di Kelas 5 Sd Tlompakan 01 - Tuntang. Scholaria, Vol. 5, No. 3, September 2015: $120-135$.

Latipun, 2004. Psikologi Eksperimen, edisi kedua. Malang : UMM Press

Purbowati, L.S. 2016. Perbedaan Pembelajaran Jigsaw Dan Diskusi Presentasi Terhadap Hasil Belajar Ipa Pada Siswa Smp Muhammadiyah 4 Surakarta. Diunduh tanggal 10 April 2017. Naskah Publikasi FKIP UMS.

Utami,Reni. 2011. Penerapan Metode Sosio Drama Untuk Meningkatkan Partisipasi Siswa Dalam Pembelajaran Sosiologi Kelas Xi Ips 1 Madrasah Aliyah Negeri Yogyakarta Iii Tahun Ajaran 2011/2012. Diunduh tanggal 11 April 2017. http://eprints.uny.ac.id/22007/1/SKRIPSI_RENI.pdf

Sujarweni,V.W. 2007. Panduan Mudah Menggunakan SPSS dan Contoh Penelitian Bidang Ekonomi. Yogyakarta : Ardana Media.

Zuhara,E. 2015. Efektivitas Teknik Sosiodrama Untuk Meningkatkan Komunikasi Interpersonal Siswa. Diunduh tanggal 11 April 2017. Jurnal Ilmiah Edukasi Vol 1, Nomor 1, Juni 2015 